ఠ

\title{
miR-32 functions as a tumor suppressor and directly targets SOX9 in human non-small cell lung cancer [Retraction]
}

The Editor-in-Chief and Publisher of OncoTargets and Therapy have been alerted to unacceptable levels of duplication with another published paper: Zhu D, Chen H, Yang X, Chen W, Wang L, Xu J and Yu L. Decreased microRNA-224 and its clinical significance in non-small cell lung cancer patients. Diagnostic Pathology. 9;198:2014.
Accordingly, we retract Zhu D, Chen H, Yang X, Chen W, Wang L, Xu J, Yu L. miR-32 functions as a tumor suppressor and directly targets SOX9 in human non-small cell lung cancer. OncoTargets and Therapy. 2015;8:1773-1783.
OncoTargets and Therapy

\section{Publish your work in this journal}

OncoTargets and Therapy is an international, peer-reviewed, open access journal focusing on the pathological basis of all cancers, potential targets for therapy and treatment protocols employed to improve the management of cancer patients. The journal also focuses on the impact

of management programs and new therapeutic agents and protocols on

\section{Dovepress}

patient perspectives such as quality of life, adherence and satisfaction. The manuscript management system is completely online and includes a very quick and fair peer-review system, which is all easy to use. Visit http://www.dovepress.com/testimonials.php to read real quotes from published authors. 